\title{
Recovery of Valencia Groundnut (Arachis hypogaea L.) Traits in Early Segregating and Promising Late Leaf Spot Resistant Populations
}

\author{
W. Wambi ${ }^{*}, 1$, R.G. Nalugo ${ }^{1}$, P. Tukamuhabwa ${ }^{2}$, D.K. Okello ${ }^{3}$, N. Puppala ${ }^{4}$ \\ ${ }^{1}$ National Agricultural Research Organization. ${ }^{2}$ Department of Agricultural Production, School of \\ Agricultural Sciences, Makerere University. ${ }^{3}$ National Semi-Arid Resources Research Institute. ${ }^{4}$ New Mexico \\ State University

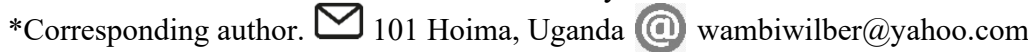

\begin{abstract}
In Uganda, there are no Valencia varieties that are resistant to leaf spot diseases. Introgression of resistance genes into elite lines is always associated with the transfer of undesirable traits from the donor parents. Knowledge of the degree of genetic relationship provides breeders with a more efficient way to identify populations of potential relevance for their plant improvement programs. The objective of this study was to determine the recovery of Valencia groundnut traits in the early segregating and promising late leaf spot (LLS) resistant populations. Four crosses between Valencia lines (P1) and donor lines (P2) were made. The populations that included $\mathrm{F} 1, \mathrm{~F} 2, \mathrm{BC} 1 \mathrm{P} 1$ and $\mathrm{BC} 1 \mathrm{P} 2$, together with their parents (P1and $\mathrm{P} 2)$ of each of the four crosses namely, Valencia C (P1) × ICGV-SM $02501(\mathrm{P} 2)$, Valencia C (P1) $\times$ SGV-07009 (P2), NuMexM3 (P1) × ICGV-SM $02501(\mathrm{P} 2)$ and Redbeauty (P1) $\times$ ICGV-SM $03590(\mathrm{P} 2)$ were evaluated. Cluster analysis revealed differences among the generations for the traits analysed with major and sub-clusters, implying that the generations of crosses formed a genetically diverse population that offers possible opportunity for selection. In the cross between NuMex-M3 X ICGV-SM 02501, the populations BC1P1 and F2, exhibited higher $(80 \%)$ recovery of the recurrent parental (NuMex-M3) traits. Similarly, the backcross population (BC1P1) to the susceptible elite variety of the Valencia C X ICGV-SM 02501 cross recovered approximately $75 \%$ of the recurrent parental traits Valencia C with lower LLS disease score. Such populations could result in higher gain in Valencia traits and LLS resistance when utilized the breeding program. For maximum gain in LLS resistance and recovery of Valencia traits, more selfing and backcrossing can be performed to fix the genes for LLS resistance as well those of Valencia characteristics.
\end{abstract}

Keywords: cluster analysis, Arachis hypogaea, diverse populations.

\section{INTRODUCTION}

The cultivated groundnut (Arachis.hypogaea) is an annual herb with two subspecies. The subspecies hypogaea have been characterized by absence of flower on the main stem and alternate vegetative and reproductive nodes. It includes two botanical varieties bypogaea (Virginia bunch and Virginia runner types) and the less-frequently cultivated birsuta. The fastigiata subspecies is typified by flowers on the main stem and sequential reproductive nodes. It has four botanical varieties, fastigiata (Valencia type), vulgaris (Spanish type), peruviana, and aequatoriana (Krapovickas and Gregory, 1994).

In Uganda, there are no Valencia varieties that are resistant to leaf spot diseases (Okello et al., 2010). The Valencia varieties are known for their highest score 
for sweet taste and having three to five seeds per pod when compared with other botanical types (Patte et al., 2001) valued by farmers because of earlier maturity and more convenient to cultivate. Traders also prefer Valencia due to higher oil content (Kaaya and Warren, 2005).

To broaden Valencia genetic base in Uganda, new high yielding breeding Valencia lines (Valencia C and NewMex$\mathrm{M}_{3}$ ) were introduced from New Mexico state USA and evaluated for resistance and tolerance to abiotic (drought) and biotic stresses (leaf spot, rosette and rust diseases and pests) at National Semi-Arid Resources Research Institute (NaSARRI) in Uganda. However, these cultivars were found susceptible to leaf spot diseases (Okello et al., 2010). Sources of resistance to LLS were identified in ICGV-SM 03590 and ICGV-SM 02501 from ICRISAT Malawi, and SGV AL (advanced breeding line) lines which are Virginia and Spanish types (Okello et al., 2010). The use of these lines in the introgression of high-level leaf spot resistance into agronomically desirable and high yielding groundnut varieties will be the most effective and economical management option under resource-limited farming systems in developing countries. However, introgression of resistance genes into elite lines is always associated with the transfer of undesirable traits from the donor parents. The objective of this study was to determine the morphological relationship among Valencia parental lines and their derived early segregating and promising late leaf spot (LLS) resistant populations. Knowledge on the degree of genetic relationship will help breeders in designing more efficient and effective breeding programs which will enhance the development and utilization of desirable LLS resistant cultivars with acceptable Valencia traits.

\section{METHODS}

The research was conducted at the National Semi-Arid Resources Research
Institute (NaSARRI) of the National Agricultural Research Organization (NARO) located $01^{0} 3000 \mathrm{~N}$ and $33^{\circ} 33$ $00 \mathrm{E}$ in Serere district, Uganda. This location represents a humid and hot climate that receives an annual rainfall $1,000-1,200 \mathrm{~mm}$.

\section{Materials}

In the study seven groundnut genotypes (Table 1), with varying levels of response to LLS were used. The genotype had been characterized for resistance to LLS by the Groundnut Improvement Programme at NaSARRI. Four crosses between Valencia (P1) and donor (P2) lines were made. The six generations namely $\mathrm{P}_{1}, \mathrm{P}_{2}, \mathrm{~F}_{1}, \mathrm{~F}_{2}$ and $\mathrm{BC}_{1} \mathrm{P}_{1}$ and $\mathrm{BC}_{1} \mathrm{P}_{2}$ of each cross of the four crosses viz:, Valencia C (P1) $\times$ ICGV-SM 02501 (P2), Valencia C (P1) × SGV-07009 (P2), NuMex-M3 (P1) × ICGV-SM 02501 (P2) and Redbeauty (P1) × ICGV-SM 03590 (P2) were set in a randomized complete block design (RCBD) in three replicates with 2-row-plots of ten plants each. The populations and parental lines were planted in the field at a spacing of 45 $\mathrm{cm} \times 15 \mathrm{~cm}$, and the experiment was kept free of weeds throughout the cropping season. The groundnut line JL 24 which is highly susceptible to late leaf spot was used as a spreader row to maintain the effective inoculum load.

\section{Data Collection}

Late leaf spot disease severity scoring was done at 115 days after planting using a modified nine-point scale (Subrahmanyam et al., 1995) for all populations of each of the four crosses that were made. Measurements were taken on the following morphological traits that included; Growth habit, number of branches per plant, peg colour, stems pigmentation, stem hairiness, pod reticulation, pod constriction, pod beak and seed characteristics following the International Board for Plant Genetic 
Resources (IBPGR, 1992) groundnut descriptor guidelines (Table 1). The data was collected on healthy plants on only populations of Valencia C (P1) $\times$ ICGVSM 02501 (P2) and NuMex-M3 X ICGV-
SM 02501 crosses. The populations from other crosses were high affected by groundnut rosette and no healthy pods available for data collection hence were excluded for further analysis.

Table 1. Botanical types, Origin, pedigree, and response to LLS of six groundnut lines

\begin{tabular}{|c|c|c|c|c|}
\hline Genotype & $\begin{array}{l}\text { Botanical } \\
\text { types }\end{array}$ & Pedigree & Origin & Response to LLS \\
\hline Redbeauty & Valencia & Landrace & Uganda & Susceptible \\
\hline Valencia C & Valencia & $\begin{array}{l}\text { Selection from Colorado } \\
\text { Manfredi }\end{array}$ & USA & Susceptible \\
\hline $\mathrm{NuMex}^{-\mathrm{M}_{3}}$ & Valencia & Valencia C × ICGV 87157 & USA & Susceptible \\
\hline JL 24 & Spanish & 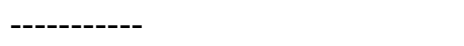 & India & Highly susceptible \\
\hline $\begin{array}{l}\text { ICVG-SM } \\
\text { O3590 }\end{array}$ & Virginia & ----------- & Malawi & Resistant \\
\hline ICGV-SM 02501 & Spanish & ------------ & Malawi & Resistant \\
\hline SGV 07009 & Virginia & SGV 91707× Serenut 1 & Uganda & Resistant \\
\hline
\end{tabular}

Table 2. Description of the morphological traits

\begin{tabular}{|c|c|c|}
\hline Trait & Stage recorded & Score \\
\hline Growth habit & $\begin{array}{l}\text { Recorded at podding stage } \\
\text { at } 10-15 \mathrm{~cm} \text { inter plant } \\
\text { spacing }\end{array}$ & $\begin{array}{l}\text { 1.Procumbent-1; } \\
\text { 2.Procumbent-1 } \\
\text { 3. Decumbent-1; } \\
\text { 4. Decumbent-2; } \\
\text { 5. Decumbent-3; } \\
\text { 6. Erect }\end{array}$ \\
\hline $\begin{array}{l}\text { Number of } \\
\text { branches per plant }\end{array}$ & Numbers & $\begin{array}{l}\text { Primary }(n+1) \\
\text { Secondary }(n+2) \\
\text { Tertiary }\end{array}$ \\
\hline Peg colour & $\begin{array}{l}\text { Recorded on plants after } \\
50 \% \text { flowering }\end{array}$ & $\begin{array}{l}0=\text { Absent } \\
1=\text { Present }\end{array}$ \\
\hline $\begin{array}{l}\text { Stems } \\
\text { pigmentation }\end{array}$ & Recorded on mature plants & $\begin{array}{l}0=\text { Absent } \\
1=\text { Present }\end{array}$ \\
\hline Stem hairiness & Recorded on mature plants & $\begin{array}{l}0=\text { Absent } \\
1=\text { Present }\end{array}$ \\
\hline Pod beak & Recorded on dry pods & $\begin{array}{l}0=\text { Absent } / \text { None }, \\
3=\text { Slight } \\
\text { 5=Moderate } \\
7=\text { Prominent } \\
9=\text { Very Prominent }\end{array}$ \\
\hline $\begin{array}{l}\text { Pod beak } \\
\text { reticulation }\end{array}$ & Recorded on dry pods & $\begin{array}{l}0=\text { Absent } / \text { None } \\
3=\text { Slight } \\
5=\text { Moderate }\end{array}$ \\
\hline
\end{tabular}


Pod constriction

Seed

characteristics

Late leaf spot disease
At harvest on a

Subrahmanyam et al., 1995 scale of 1-9
$7=$ Prominent

9=Very Prominent

$0=$ Absent/None,

$3=$ Slight

$5=$ Moderate,

$7=$ Prominent

9=Very Prominent

1.One colour

2. Variegated

1: No disease (0\%), 2: 1-5\%, 3: 6-10\%, 4:

11-20\%, 5: 21-30\%, 6: 31-40\%, 7: 41-60\%, 8: $61-80 \%$ and $9: 81-100 \%$

\section{Analysis}

Data taken on the generations of each cross were subjected to analysis of variance (ANOVA) using GenStat version 13 software to test for the significance of the differences between the generations' means of each cross for the LLS disease scores. The generation means were compared using Fisher's protected least significant difference test at 5\% level of probability (Payne et al., 2010).Descriptive statistics were used to generate the mean for descriptors. Hierarchical cluster analysis was performed following the unweighted pair group method of the average arithmetic procedure [UPGMA] based on
Euclidean coefficient using GenStat computer package [13 the edition Version 13.3.

\section{RESULTS}

\section{Late Leaf Spot Resistance Trait}

ANOVA for the four crosses NuMex-M3 $\times$ ICGV-SM 02501, Valencia C × ICGVSM 02501, Redbeauty × ICGV-SM 03590 and Valencia $\mathrm{C} \times$ SGV-07009 showed significant differences among generations for LLS scores $(\mathrm{P} \leq 0.01)$ (Table 3$)$.

Table 3. Results of LLS mean score for the six generations of the four crosses.

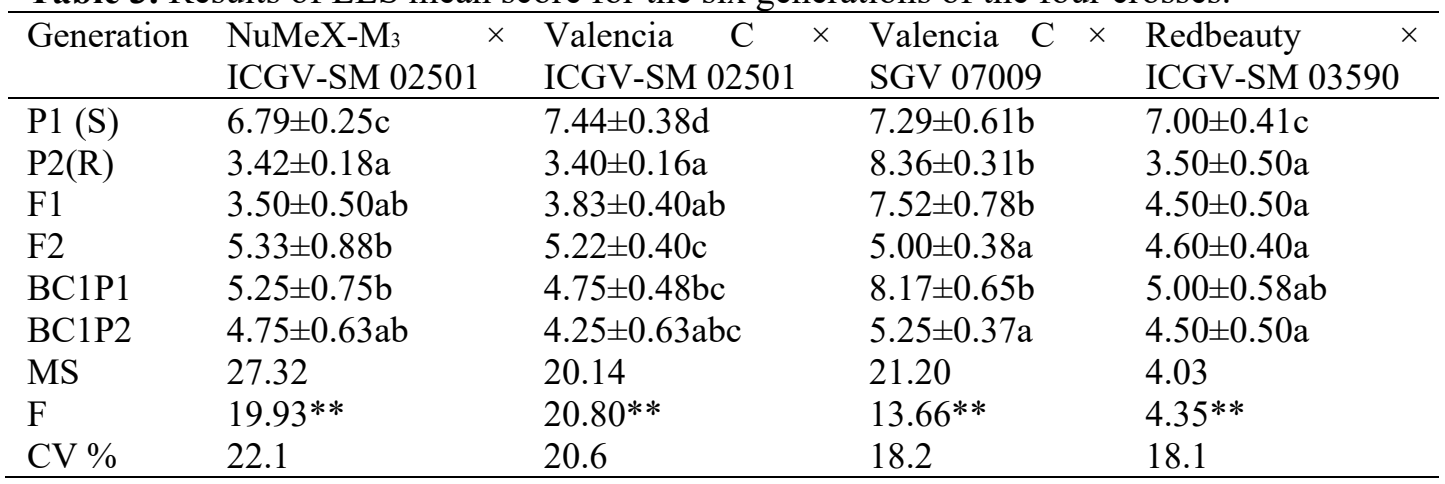

$\mathrm{P} 1(\mathrm{~S})=$ Susceptible parent, $\mathrm{P} 2(\mathrm{R})=$ resistant parent, $\mathrm{F} 1=$ first filial generation, $\mathrm{F} 2=$ Second filial generation, $\mathrm{BC} 1 \mathrm{P} 1=$ Backcross to susceptible parents $(\mathrm{P} 1)$ and $\mathrm{BC} 1 \mathrm{P} 2=$ Backcross to resistant parent $(\mathrm{P} 2), \mathrm{MS}=\mathrm{Mean}$ sum of square, $\mathrm{F}=$ Variation ratio, ${ }^{* *}=$ significant at $\mathrm{P}<0.01, \mathrm{CV}=$ Coefficient of variation. 
Table 4. Mean of morphological characteristics for the populations of two crosses

\begin{tabular}{|c|c|c|c|c|c|c|c|c|c|c|}
\hline Generations & $\begin{array}{c}\text { Growth } \\
\text { habit }\end{array}$ & $\begin{array}{l}\text { Branch } \\
\text { number }\end{array}$ & $\begin{array}{l}\text { Stem } \\
\text { pigmentation }\end{array}$ & $\begin{array}{l}\text { Peg } \\
\text { colour }\end{array}$ & $\begin{array}{l}\text { Stem } \\
\text { hairiness }\end{array}$ & Pod beak & $\begin{array}{l}\text { Pod } \\
\text { reticulation }\end{array}$ & Seed colour & Seed number/pod & $\begin{array}{l}\text { Pod } \\
\text { constriction }\end{array}$ \\
\hline \multicolumn{11}{|c|}{ NuMeX-M3 × ICGV-SM 02501} \\
\hline BC1P1 & 4.75 & 13.00 & 0.00 & 0.00 & 0.00 & 0.00 & 3.00 & 1.00 & 1.00 & 0.00 \\
\hline $\mathrm{BC} 1 \mathrm{P} 2$ & 3.88 & 6.75 & 0.50 & 1.00 & 0.75 & 4.33 & 2.00 & 1.00 & 1.67 & 0.00 \\
\hline $\mathrm{F} 1$ & 4.80 & 10.00 & 0.33 & 0.33 & 0.33 & 5.00 & 4.33 & 1.00 & 2.00 & 3.67 \\
\hline $\mathrm{F} 2$ & 3.33 & 9.83 & 0.25 & 0.25 & 0.25 & 1.00 & 1.00 & 1.00 & 2.33 & 0.00 \\
\hline ICGV 02501 & 4.00 & 23.00 & 1.00 & 1.00 & 1.00 & 9.00 & 9.00 & 2.00 & 2.00 & 8.60 \\
\hline NuMeX-M3 & 6.00 & 4.50 & & & & 0.00 & 0.00 & 1.00 & 3.00 & 0.00 \\
\hline \multicolumn{11}{|c|}{ Valencia CX ICGV 02501} \\
\hline $\mathrm{BC} 1 \mathrm{P} 1$ & 4.67 & 13.75 & 0.50 & 0.25 & 0.50 & 1.80 & 2.40 & 1.00 & 2.60 & 1.20 \\
\hline $\mathrm{BC} 1 \mathrm{P} 2$ & 4.00 & 20.00 & 0.50 & 0.00 & 0.50 & 6.60 & 5.80 & 1.60 & 2.40 & 7.40 \\
\hline $\mathrm{F} 2$ & 4.00 & 18.33 & 0.33 & 0.00 & 1.00 & 4.60 & 5.80 & 2.00 & 2.60 & 6.20 \\
\hline ICGV 02501 & 4.00 & 23.00 & 1.00 & 0.00 & 1.00 & 9.00 & 9.00 & 2.00 & 2.00 & 8.60 \\
\hline Valencia C & 6.00 & 4.00 & 0.00 & 0.00 & 0.00 & 1.20 & 1.20 & 1.00 & 3.00 & 0.60 \\
\hline
\end{tabular}


In the crossing that involved Valencia C and ICGV-SM 02501 parental lines, the susceptible parental line Valencia C had erect growth habit with an average of four branches/plant and had no peg colour, stem pigmentation, and hairs while ICGVSM 02501 had a decumbent growth habit with an average of 23 branches/plant and with peg colour, pigmented and hairy stems. The F2 population had 18 branches, followed the decumbent growth habit with hairy stems but lacked peg colour and stem pigmentation. The backcross to the susceptible parent (BC1P1) had 14 branches, hairy and pigmented stems with no peg colour and segregated towards an erect growth habit. The BC1P2 populations had 20 branches, hairy and pigmented stems with no peg colour and segregated

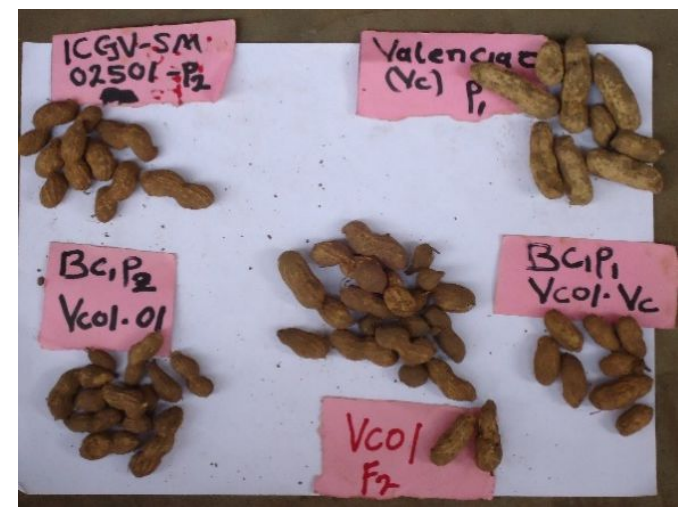

Plate 1

In the NuMeX-M3 $\times$ ICGV-SM 02501 cross, the donor and recurrent exhibited decumbent and elect growth habit respectively. Most of the F2 and BC1P2 plants showed more decumbent growth habit of the donor plants whereas BC1P1 plants segregated more towards the recurrent plantable 4. The recurrent parental and donor lines had an average branch number of 5 and 23 per plant. All the segregating populations exhibited branch numbers less than that of the donor's parent. With the exception of BC1P2 population, all other populations of towards the decumbent growth habit (Table 4). The susceptible elite variety had no pod constrictions, pod beaks, and reticulations on their pods but had three red seeds/pod on average. For pod and seed characteristics, the backcross population (BC1P1) to the susceptible elite variety exhibited no beak, reticulation, and constriction on their pods like the elite variety and as well segregated towards the three red seeded traits of the elite variety (Plate 1 and 2). The backcross population (BC1P2) exhibited prominent constriction, moderate beak and reticulation on their pods and had on average two tan seeded pods (Plate 1 and 2). The F2 populations exhibited moderate constriction, beak, and reticulation on their pods and had on average three tan seeded pods.

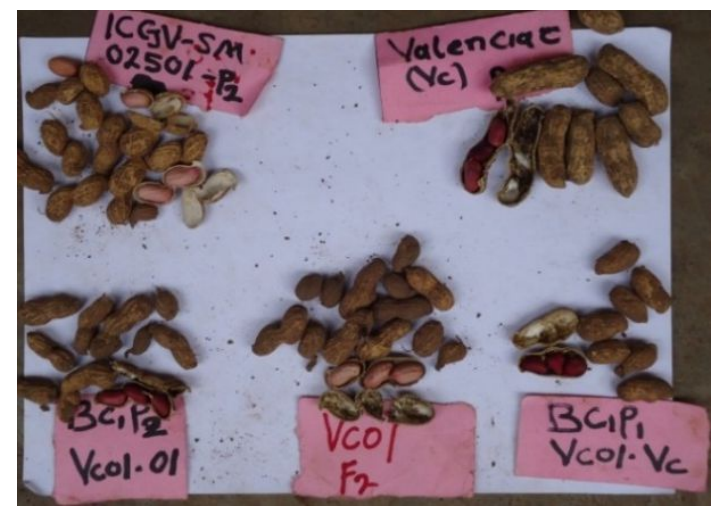

Plate 2

this cross had lacked stem pigmented and hairs, and peg colour like the NuMeX-M3 line. The donor parent had pods with very deep constriction, and prominent pod beak and reticulation whereas the NuMeX-M3 parental lines had no constrictions, beaks, and reticulations on their pods. Implying that most of the population segregated towards the recurrent parents. On average the NuMeX-M3 parental lines had three red seeds/pod while the donor line ICGVSM 02501 had 2 tan seeds/pod. All the segregating populations exhibited only two red seeded pods. 


\section{Cluster Analysis}

For the cross between Valencia $\mathrm{C}$ and ICGV-SM 02501 (Figure 1), the similarity between the parental line Valencia $\mathrm{C}$ and other generations including the resistant parental line was approximately 50\%. The population BC1P1 was approximately $75 \%$ similar to Valencia $\mathrm{C}$ line. The populations BC1P2 and F2 populations were approximately $\quad 95 \%$ similar and approximately $87 \%$ similar to ICGV-SM 02501 the resistant line. For the cross NuMex-M3 X ICGV-SM 02501 (Figure 2), the resemblance between the parents based on the analysed traits was approximately $41 \%$. The populations F1, BC1P1, and F2, were approximately $85 \%$ and $80 \%$ similar to the recurrent line NuMex-M3 respectively.

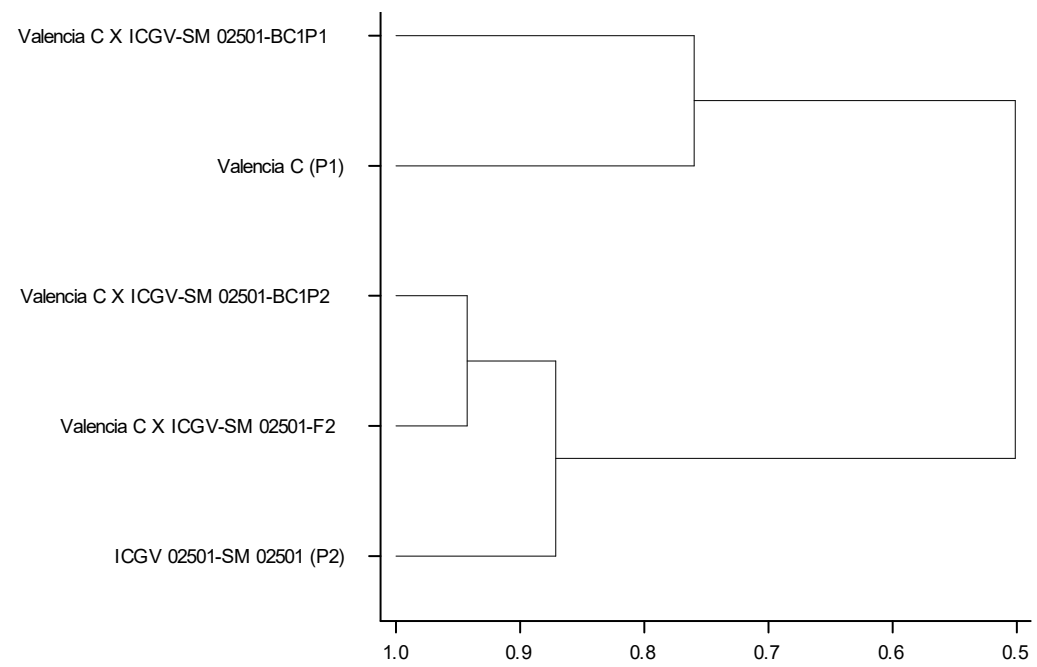

Figure 1. Dendrogram of genetic distances among populations of Valencia $\mathrm{C} \times \mathrm{ICGV}-\mathrm{SM}$ 02501 cross

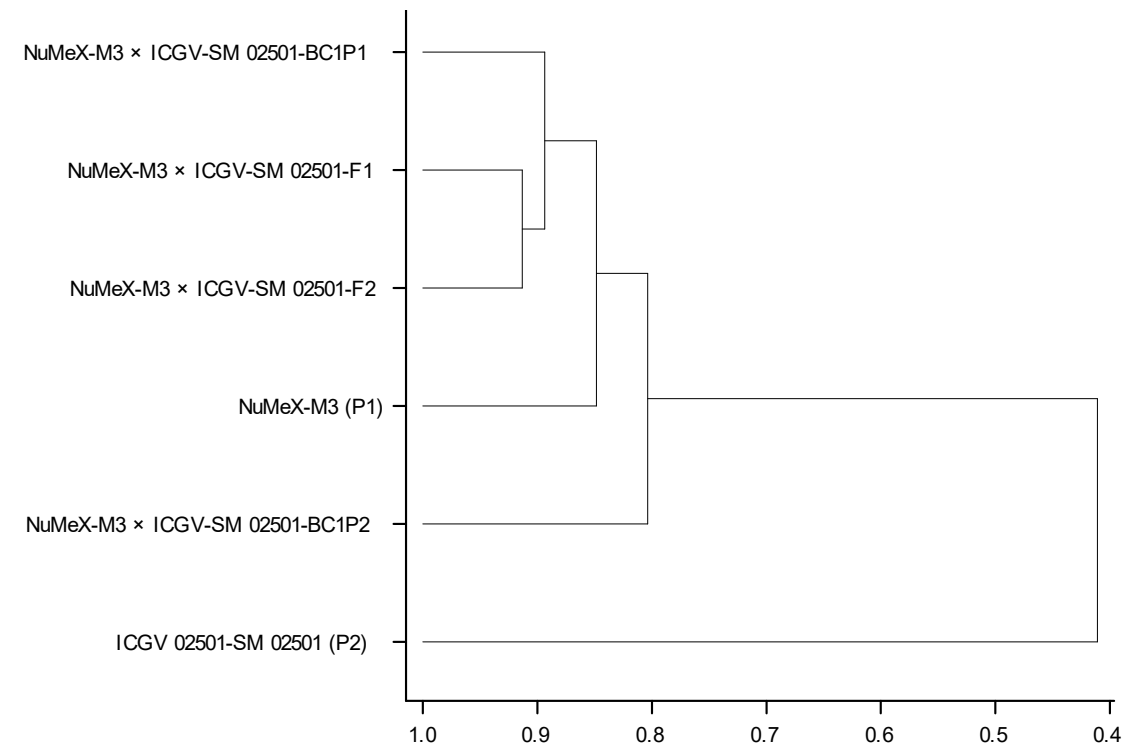

Figure 2. Dendrogram of genetic distances among generations of NuMex-MB $\times$ IOGVSM02501 cross 


\section{DISCUSSION}

Moderate to high levels of LLS resistance was observed in all populations of the crosses. The resistance that was exhibited among the populations of the crosses depended on the genetic background of the parents that were used in the hybridization. In general, the backcrosses, BC1P1 and BC1P2 showed the mean LLS disease score close to recurrent and donor parents respectively Table 2 . The F2 population of the crosses showed moderate highly resistant to LLS. This considerable amount of variability for LLS resistance among the different populations demonstrates additional opportunities for improving groundnut for resistance to LLS through selection. The parental line, SGV-07009 exhibited non-significant difference for late leaf spot disease scores as compared with Valencia $\mathrm{C}$ the recurrent parent.

Consequently, its derived populations succumbed to LLS disease except for F2 and BC1P2. Therefore, its populations were excluded for further analysis due to lack of healthy plants for observation. Such progenitor (SGV-07009) should be excluded from the breeding program for LLS resistance because of its weak performance. Similarly, though promising moderate to high LLS resistant segregating populations were recorded from Red beauty x ICGVSM-03590 cross, their podding was highly affected by groundnut rosette disease, and were also excluded for further analysis. These promising populations can be improved by pyramiding LLS and groundnut rosette genes. Though line ICGVSM-03590 combined well for LLS resistance, its combining ability for groundnut rosette was poor with Red beauty. The line exhibited high tolerance to groundnut rosette disease compared to its derived populations. Additionally, it has been reported as a potential donor for groundnut rosette disease Okello et al., (2010). Hence it's important to test such a good LLS progenitor for its combining ability with other genetic parental background to ensure dual transfer for LLS and groundnut rosette resistance. Nalugo et al, (2016) concluded that heritability of a trait is a property of the genetic back ground of a population being studied and the environment circumstances to which the individuals are subjected.

The Cluster analysis revealed moderate to high recovery of Valencia traits among promising early segregating LLS resistant populations of NuMex-M3 X ICGV-SM 02501 and Valencia C X ICGV-SM 02501 crosses with major and sub-clusters (Fig 1 and 2). This indicated the various segregation and recombination levels that occurred which contributed to significant variability among the generations for the analysed morphological Valencia traits that could offer possible opportunities for selection in the populations. Pattee et al. (2001) reported that segregation within crosses provides additional opportunity for progress from the selection. The results are comparable to those of Kroonenberg et al. (2012) who observed morphological variation in section Arachis. (Garba et al., 2015) also revealed four distinct groups for hundred groundnuts (Arachis bypogaea L.) varieties based on Hierarchical Clustering (AHC) and Fisher Discriminant Analysis (FDA) using twenty-four (24) agromorphological traits.

All the parents that were used to generate crosses had contrasting morphological traits which add more evidence that the parental lines were distinct and belonged to different groundnut botanical varieties. The recurrent parental lines NuMex-M3 and Valencia C belong to fastigiata (Valencia type) while ICGV-SM 02501 belongs to vulgaris (Spanish type). The results are comparable to those of Krapovickas and Gregory, (1994) who reported four groundnut botanical varieties based on morphological characterization, fastigiata 
(Valencia type), vulgaris (Spanish type), peruviana, and aequatoriana

In the current study, the genetic distance between the parental lines was approximately $50 \%$ and 59 respectively for Valencia C X ICGV-SM 02501 and NuMex-M3 X ICGV-SM 02501 crosses (Figure 1 and 2). This great distance could have contributed to the maximum vigour that was observed in the populations that were derived from these divergent progenitors. The results are in agreement with that of (Oliveira \& Valls, 2003) who reported that the most vigorous hybrid in field experiments originated from the parental accessions that verified between the most morphologically divergent progenitors, $A$. pintoi GK 12787 and $A$. repens Nc 1579. The accessions GK 12787 and Nc 1579 that presented the maximum Euclidian distance (5.52) resulted to most vigorous hybrids compared to V 13468 and Nc 1579 which exhibited minimum Euclidian distance (0.20). According to Nalugo et al (2014), genetic distance can be an adequate parameter for choosing parental combinations in a crossing program peanut accessions for improving the Valencia background that have a relatively higher number of seeds (4-5 seeds/pod). Therefore, these more distinct lines could be recommend for use as parents in hybridisation for improving Valencia groundnuts for LLS resistance.

In the cross between NuMex-M3 X ICGV-SM 02501, the populations BC1P1 and F2, exhibited higher recovery (approximately $80 \%$ ) of the recurrent parental (NuMex-M3) traits. Similarly the backcross population (BC1P1) to the susceptible elite variety of the Valencia C X ICGV-SM 02501 cross exhibited no beak, reticulation and constriction on their pods like the elite variety and as well segregated towards the three red seeded trait of the elite variety and hence recovered more of the recurrent parental traits (approximately $75 \%$ similarity to Valencia C) with lower
LLS disease score. Such populations could result in higher gain in Valencia traits and LLS resistance when utilized in the breeding program. The finds confirm to that of (Nalugo et al., 2014) who reported moderate to the high recovery of Valencia traits in crosses that involved Valencia and Spanish botanical types.

The backcross population (BC1P2) of Valencia C X ICGV-SM 02501 cross had reduced prominent constriction, moderate beak and reticulation compared to donor lines that shown very deep prominent beak, reticulation, and constriction on their pods with very low LLS disease score. Suggesting that population slightly segregated to towards the elite variety which grantee opportunities for improvement such a population with high resistance to LLS in advanced stages of selection. More backcrosses can be made to fix the Valencia traits in the advanced hybridization breeding program. According to Poehlman and Sleper (1996), the backcross method is important in recovering the recurrent parent traits in the populations after hybridization.

\section{Conclusion and Recommendation}

In the current study, it was revealed that early segregating populations of crosses form genetically diverse populations that offer possible opportunities for selection and enhancing genetic gain in Valencia traits and LLS resistance when advanced in the breeding program. For maximum gain in LLS resistance and recovery of Valencia traits, more selfing and backcrossing can be performed to fix the genes for LLS resistance as well those of Valencia characteristics.

\section{ACKNOWLEDGMENT}

This study was supported by the United States Agency for International Development (USAID) under the Peanut 
CRSP grant ECG-A-00-07-0001-00. We also acknowledge NaSARRI/NARO for providing germplasm, helping with the hybridization and field operations.

\section{REFERENCES}

Garba N, M. I., Bakasso, Y., Zaman -Allah, M., Atta, S., Mamane, M, I., Adamou, M., and Saadou, M. (2015). Evaluation of agro-morphological diversity of groundnut (Arachis hypogaea L.) in Niger. African Joumal of Agricultural Research, 10(5), 334-344.

Kaaya N. A. and H.L .Warren (2005). A Review of Past and Present Research on Aflatoxin in Figure Uganda. Afr. J. Food, Agric. Nutr. Dev. Volume 5, No. 1. Available on line.

Krapovickas, A., and W. C. Gregory. 1994. Taxonomy of the genus Arachis (Leguminosae). Figure Bonplandia 8:1186.

Kroonenberg. P.M, B.D. Harch, K.E. Basford, and A. Cruickshank.2012. Combined Analysis

Figure of Categorical and' Numerical Descriptors of Australian Groundnut Accessions Using Figure Nonlinear Principal Component Analysis. International Biometric Society Stable Nalugo, R. G., Ssebuliba, J. M., Okello, D. K., \& Puppala, N. (2014). Recovery of morphological traits associated with the Valencia botanical group in segregating groundnut [Arachis hypogaea L] generations in Uganda. African Journal of Applied Agricultural Sciences and Technologies, 57-68.

Nalugo, R. G., Wambi, W., Sebbuliba, J. M., Okello, D. K., \& Puppala, N. (2016). Heritability for resistance to rosette disease in Exotic Valencia Groundnuts. African Crop Science Journal, 24(2), 203211.

Okello K.D., Deom, C. and Puppala, N. 2010. Screening groundnut Accessions for Rosette and Figure Leaf spot
Diseases in Uganda. Long Beach Convention Centre, Exhibit Hall BC, Figure Lower Level

Oliveira, M. A. P., \& Valls, J. F. M. (2003). Morphological characterization and reproductive aspects in genetic variability studies of forage peanut. Scientia Agricola, 60(2), 299-304. https://doi.org/10.1590/s010390162003000200014

Pattee, H.E., Isleib, T.G., Gorbet, D.W., Giesbrecht, F.G. and Cui, Z. (2001). Parental selection in breeding for roasted peanut flavour quality. Peanut Science. 28: 51-58. Figure

Payne, R., W.S.A. Harding, D.A. Murray, D.M. Soutar, D.B. Baird, A.I. Glaser, I.C. Channing, Figure S.J. Figure Welham, A.R. Gilmour, R. Thompson, R. Webster.(2010).A Guide to ANOVA Figure and Design in Figure Gen Stat. 13th Edn. VSN International ltd.pp1103

Poehlman J.M and Sleper.D.A.1996.Breeding Field Crops. $4^{\text {th }}$ Edn. Iowa State University Figure Press/Ames

Subrahmanyam P, McDonald D, Waliyar F, Reddy LJ, Nigam SN, Gibbons, RW, Rao FigureVR., Singh AK, Pande S, Reddy PM, Rao PVS (1995). Figure Screening methods and Figure sources of resistance to rust and late leaf spot of groundnut. Information bulletin Figure No: Figure47 ICRISAT. 